\title{
A Very Rare Case: Recurrent Paratesticular Leiomyosarcoma
}

\section{Çok Nadir Görülen Bir Olgu: Nüks Paratestiküler Leiomyosarkom}

Olgu Sunumu Case Report

\author{
Mehmet Zeynel Keskin $\oplus^{\oplus}$, Yusuf Özlem ilbey $\oplus^{\oplus}$, Samir Abdullazade ${ }^{\oplus}$, Erdem Kısa ${ }^{\oplus}$, \\ Cem Yucel $\odot$, Okan Nabi Yalbuzdag ${ }^{\oplus}$
}

\section{ABSTRACT}

Subcutaneous superficial LMS is quite rare and does not involve testicular, epididymal, and spermatic cord soft tissues. In brief, scrotal subcutaneous LMS is seen in 1/250000 of all malignancies. Here we aimed to present local recurrence of this rarely seen pathology in this case report.

Keywords: Leiomyosarcoma, Paratesticular, Recurrent

öz

Subkütanöz yüzeysel LMS oldukça nadirdir ve testis, epididim, spermatik kord gibi dokuları içermez. Özetle, skrotal subkütanöz LMS tüm malignitelerin 1/250000'ünde görülür. Bu olgu sunumunda bu nadir görülen patolojinin lokal nüksünü sunmayı amaçladık.

Anahtar kelimeler: Leiyomyosarkom, Paratestiküler, Nüks

\section{INTRODUCTION}

Leiomyosarcoma (LMS) is a tumor that stems from soft tissue. Soft tissue sarcomas (STSs) stem from mesenchymal tissue and represent less than $1 \%$ of all adult malignancies and LMS accounts for $10-20 \%$ of all STSs (1). Genitourinary LMS constitutes $2.1 \%$ of all STSs ${ }^{(2)}$. The term "paratesticular LMS" includes LMS involving testicular tunica (48\%), spermatic cord (48\%), epididymis (2\%), and dartos muscle and scrotal subcutaneous tissue (2\%) (1). Subcutaneous superficial LMS is quite rare and does not affect tissues of testis, epididymis, and spermatic cord ${ }^{(3)}$. In brief, scrotal subcutaneous LMS is seen in $1 / 250000$ of all malig- nancies. In this case report, we aimed to present local recurrence of this rarely seen pathology.

\section{CASE REPORT}

A 63-year-old male patient.was admitted to clinic due to right scrotal swelling. His detailed anamnesis revealed no history of radiotherapy and chemotherapy. It was determined in our hospital database review that a scrotal ultrasonography (USG) was taken on $02 / 17 / 2016$ again due to swelling in the right hemiscrotum and a $21 \times 20$ $\mathrm{mm}$ cystic mass with dense internal echoes was detected in the epididymal head. He had normal values for testicular tumor markers at that time.

(C) Copyright Association of Publication of the T.C. Ministry of Health Izmir Tepecik Education and Research Hospital.

This journal published by Logos Medical Publishing.

Licenced by Creative Commons Attribution-NonCommercial 4.0 International (CC BY-NC 4.0) 
In the operation performed on 03/30/2016, the cystic mass was excised which is associated with scrotal subcutaneous tissue without involvement of epididymis, In the macroscopic examination of the material submitted to the pathology lab, a hard tissue of $2 \times 2 \times 1.5 \mathrm{~cm}$ in size with an irregular outer surface was defined. The cross-section of the excision material displayed mostly yellow -colored heterogeneous mass with a cream-colored central part. In the histopathological examination, the lesion showed neoplastic features, with focal areas of necrosis. The number of mitotic figures was determined as 21-22 at 10X magnification. Neoplastic cells displayed significant atypia. In neoplastic cells, immunohistochemical evaluation displayed diffuse positivity for Caldesmon, Vimentin, SMA, and focal positivity for Desmin and EMA, while negativity for CD34, CD68, PaCK, Calretinin, S100 stains. The Ki-67 proliferation index was determined as $50 \%$. The tumor had a well-defined border, close to external surgical margins, even closer than $0.1 \mathrm{~cm}$ in some places. Surgical borders were intact. Based on the findings, the case was reported as LMS Grade 3/3 according to the FNCLCC system (Figure 1).

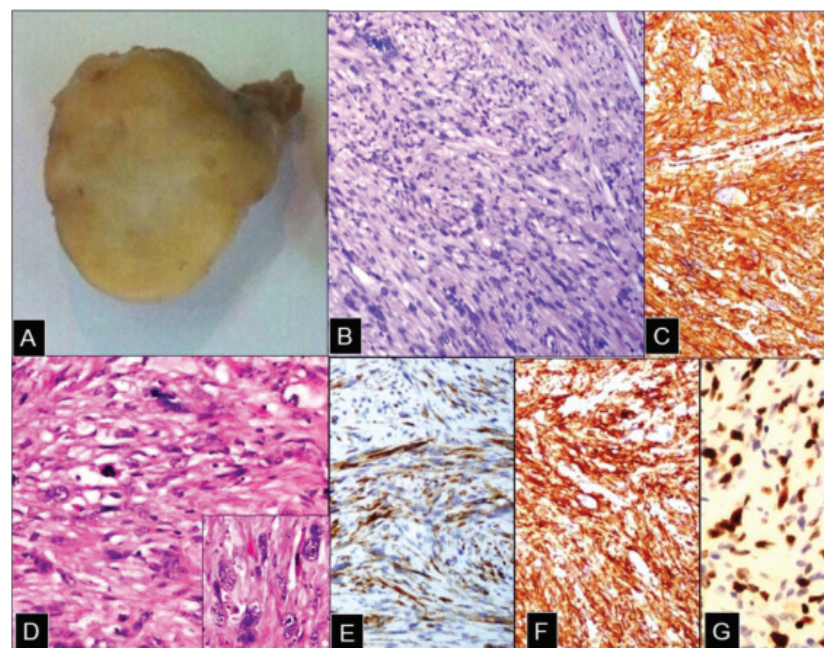

Figure 1.

Contrast-enhanced thoraco-abdominal computed tomography (CT) did not reveal any metastatic foci. Additional treatment was not considered, and follow- up protocol was approved according to medical oncology consultation. On 08/04/2016, a diagnostic excision of the surgical margin aimed for recurrence control was performed which did not reveal any evidence of tumoral invasion. The patient did not attend follow-up visits afterwards. However, in June 2018, he admitted to hospital due to recurrent right scrotal swelling (Figure 2A). His physical examination (FM) revealed that the mass was not associated with testis, but fixated to the scrotum close to the external inguinal ring. Magnetic resonance imaging (MRI) showed a well-defined solid mass of $37 \times 33 \times 35 \mathrm{~mm}$ in size with an intense contrast enhancement and localized in the right inguinal canal (Figure 2-B), which was considered to be significant in terms of recurrent mass. He underwent exploration through inguinal incision on 06/19/2018. During exploration, scrotal invasion of the mass was detected with intact testis, epididymis and cord. (Figure 2-C) The mass under the inguinal ring was excised together with the scrotal skin (Figure 2-D). A tumoral lesion with similar morphological and immunohistochemical findings was reported in the histopathological examination of the excision material. Extensive necrosis was found having 21-22 mitotic figures at 10X magnification. Like the previous mass, this recurrent tumor was also reported as LMS Grade $3 / 3$ according to the FNCLCC. For this reason, the case was considered as clinicopathologic recurrence.
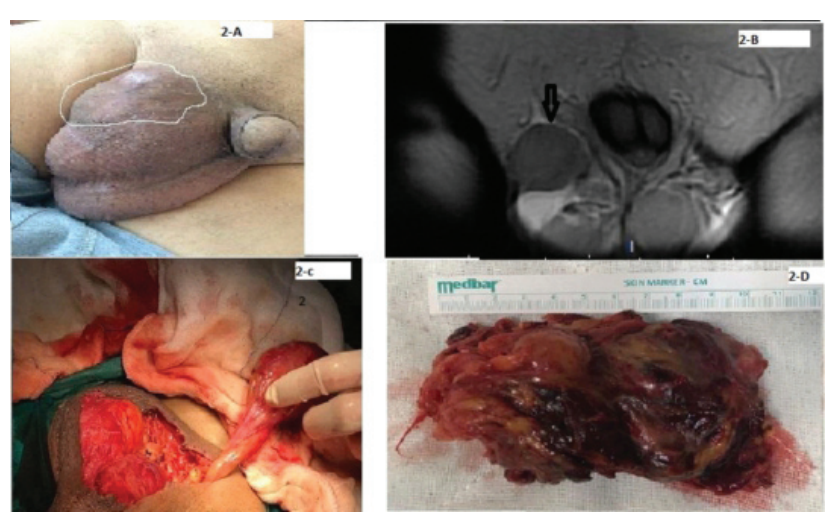

Figure 2. 


\section{DISCUSSION}

LMSs are tumors of mesenchymal origin which stem from undifferentiated smooth muscle cells. Scrotal LMS was first reported by Johnson in 1987 and can be seen in two anatomical regions as paratesticular and testicular LMS ${ }^{(4)}$. Testicular LMS constitutes $1 \%$ of all testicular malignancies and almost all of these LMS cases actually occur by local invasion of the tumor stemming from the paratesticular area ${ }^{(5)}$. In the literature, scrotal LMS cases that occurred following radiotherapy performed for cases with prostate and bladder tumor have been reported. Ekmekçi et al. reported a case who had received adjuvant radiotherapy due to prostate tumor when he was 70 years old, and admitted 2 years later with complaints of itching and redness over the penoscrotal area, and eventually he was diagnosed with LMS according to the biopsy result ${ }^{(6)}$. Scrotal LMSs are usually painless lesions. Scrotal swelling is the major complaint of these patients. On physical examination, it is palpable and hard. In differential diagnosis, benign scrotal pathologies must be kept in mind. USG and contrast-enhanced CT provide useful information for manifesting the relationship of the lesion with the surrounding tissue at the time of diagnosis. Histopathologically, cells with "cigar-shaped" nuclei are characteristic features ${ }^{(1)}$. Prameela et al. ${ }^{(4)}$ reported a case who was diagnosed with prostate cancer at the age of 77 and had been administered neoadjuvant hormonotherapy with RT. Patient was admitted 7 years later with scrotal pain and swelling, and eventually histopathologic examination result was reported as LMS. Apparently, scrotal swelling may be painful or painless in cases of LMS which are rarely seen in literature and therefore scrotal LMS should be considered in the differential diagnosis in patients complaining of scrotal swelling and redness with or without pain, especially in the follow-up period of the patients with previous RT performed for other neighboring organ tumors. What makes our case interesting is that, he had no history of RT and his scrotal subcutaneous LMS was a recurrent case. A scrotal LMS patient who had no previous RT history but underwent operation two times due to scrotal swelling was presented in a similar case report, but the pathology data of the first two operations could not be accessed ${ }^{(7)}$.

Complete resection is generally challenging in cases with scrotal LMS. The tumor can infiltrate the surrounding soft tissue and extend to the testicular parenchyma. Lymphatic spread of the tumor can reach to external iliac lymph nodes and hematogenous spread to the lungs ${ }^{(8)}$. After surgical excision, recurrence is seen in $30 \%$ of cases, metastasis in $30 \%$, and death in $30 \%$ within 4 years of follow-up. Positivity in surgical margin significantly increases the risk of local recurrence ${ }^{(9)}$. Our case showed a recurrence within two years and metastasis was not detected yet. In the literature, adjuvant radiotherapy is recommended for regional control, but RT is mostly preferred in patients who refuse operation. Although the recurrence occurred within two years in our case, it should be kept in mind that recurrence may occur after many years in the follow-up of these patients. Therefore, follow-up period should continue for a sufficiently longer periods of time in these cases with LMS.

\section{Conflict of Interest: None Informed Consent: Received}

Çıkar Çatışması: Yoktur

Hasta Onamı: Alınmıştır

\section{REFERENCES}

1. Batra A, Marwah N, Marwah S, Gupta S, Sen R. Subcutaneous leiomyosarcoma of scrotum presenting as an exophytic mass: An unusual presentation. Indian Dermatol Online J. 2015;6:193-5. [CrossRef]

2. Talikoti MA, Deo SS, Shukla NK, Kallianpur AA, Gupta M. A rare case of giant leiomyosarcoma in a filarial scrotum: $A$ case report. World J Surg Oncol. 2011;9:20. [CrossRef]

3. Dangle P, Basavaraj DR, Bhattarai S, Paul AB, Biyani CS. Leiomyosarcoma of the spermatic cord: Case report and literature review. Can Urol Assoc J. 2007;1:55-8. [CrossRef]

4. Prameela CG, Ravind R. Leiomyosarcoma of scrotum: A rare in-field second malignancy in a previously irradiated carcino- 
ma of prostate and review of literature. Journal of cancer research and therapeutics 2017;13:276. [CrossRef]

5. Siraj F, Sharma S, Rai CB, Vasudeva P. Primary high grade testicular leiomyosarcoma: A rare malignancy in a young male. Turkish journal of urology 2018;44:178. [CrossRef]

6. Ekmekci S, Tuna B, Çınar Ö, Mungan U, Yörükoğlu K. Scrotal leiomyosarcoma. The Journal of Tepecik Education and Research Hospital 2015;25:55-7. [CrossRef]

7. Agrawal R, Gupta M, Mohan N, Sharan J, Kumar P. Recurrent leiomyosarcoma scrotum: An important differential in scrotal masses. Indian Journal of Pathology and Microbiology 2017;60:581. [CrossRef]

8. Moloney J, Drumm J, Fanning DM. A rare case of paratesticular leiomyosarcoma. Clin Pract 2012;2:e29. [CrossRef]

9. Fisher C, Goldblum JR, Epstein JI, Montgomery E. Leiomyosarcoma of the paratesticular region: a clinicopathologic study. The American journal of surgical pathology 2001;25:1143-9. [CrossRef] 